\title{
Synthesis, resolution, and chiroptical properties of hemicryptophane cage controlling the chirality of propeller arrangement of a $C_{3}$ triamide unit
}

Long, A.

Jean, $M$.

Albalat, $\mathrm{M}$.

Vanthuyne, N.

Giorgi, M.

Gorecki, M.

Dutasta, J. P.

Martinez, A.

\begin{abstract}
The five-steps synthesis of a hemicryptophane cage combining a benzene-1,3,5tricarboxamide unit and a cyclotriveratrylene (CTV) moiety is described. Chiral high-performance liquid chromatography (HPLC) was used to resolve the racemic mixture. The absolute configuration of the isolated enantiomers was assigned by comparison of the experimental electronic circular dichroism (ECD) spectra with the calculated ones. X-ray molecular structures reveal that the capped benzene-1,3,5-tricarboxamide unit adopts a structurally chiral conformation in solid state: the chirality of CTV moiety controls the $\Lambda$ or $\Delta$ orientation of the three amides.
\end{abstract}

\section{1 | INTRODUCTION}

In 1981, André Collet and co-workers reported the first synthesis of a new class of chiral molecular hosts named cryptophanes, which combined two cyclotriveratrylene (CTV) units. ${ }^{1,2}$ These hosts were found to display remarkable recognition properties toward neutral molecules like methane,${ }^{3}$ atoms like $\mathrm{Xe},{ }^{4}$ anions like triflate, ${ }^{5}$ and metals or organic cations like cesium or choline. ${ }^{6,7}$ The synthesis of enantiopure cryptophanes has been also reported, allowing for the enantioselective recognition of racemic mixture of $\mathrm{CHFClBr}$ or epoxides. ${ }^{8,9}$ In 1982, the same authors published the synthesis of a new class of chiral molecular hosts, also based on the CTV unit, and named hemicryptophanes, which associate a CTV moiety with another $C_{3}$ symmetrical unit. ${ }^{10}$ This class of molecular cages was found to have a wide range of applications from molecular receptors to supramolecular catalysts and molecular machines. ${ }^{11}$

Because of the $C_{3}$-symmetrical CTV unit, hemicryptophanes are chiral molecules that can adopt the $P$ or $M$ configuration. ${ }^{12}$ Enantiopure hemicryptophanes can be obtained either by resolution of the racemic mixture or by diastereoselective synthesis. ${ }^{13}$ Besides their use as enantioselective receptors for carbohydrates and neurotransmitters, ${ }^{14-17}$ their $C_{3}$ symmetry has 
allowed to build molecular cages presenting a triple-helical arrangement of the linkers. ${ }^{18}$ Indeed, the CTV unit is able to control the chirality of triple helices since the CTV with $P$ (respectively $M$ ) configuration induces a $\Delta$ (respectively, $\Lambda$ ) propeller-like arrangement of the linkers. We thus wonder if the chirality of the CTV can control, not only the chirality of the arrangement of the linkers, but also that of the south unit, in particular that of a benzene-1,3,5tricarboxamide (BTA) moiety ubiquitous in supramolecular chemistry. ${ }^{19-27}$

Herein, we report the synthesis of the new hemicryptophane cage $\mathbf{1}$. The resolution of the racemic mixture was performed by chiral high-performance liquid chromatography (HPLC), and the assignment of the absolute configuration of the two enantiomers was achieved from electronic circular dichroism (ECD) spectra. The X-ray molecular structure of the cage shows that the chirality of the CTV unit is capable of imposing that of the capped benzotriazole (BTA) unit, which constitutes the south part of the hemicryptophane $\mathbf{1}$.

\section{2 | MATERIALS AND METHODS}

\section{1 | Synthesis and materials}

\subsection{1 | Chemicals and materials}

Starting material and solvents were of commercial-grade and were used without further purification. Chromatography was carried out with Merck 60 A $(0.040-0.063 \mathrm{~mm})$ silica gel. TLC was performed with Merck silica gel 60 F254 plates. Melting points were determined with a Büchi Melting Point B-545. Infrared (IR) spectra were obtained using a Bruker Alpha Platinum ATR. ${ }^{1} \mathrm{H}$ nuclear magnetic resonance (NMR) and ${ }^{13} \mathrm{C}$ NMR spectra were recorded at $298 \mathrm{~K}$ on a Bruker Avance III HD 300, 400, or $500 \mathrm{MHz}$ spectrometer. ${ }^{1} \mathrm{H}$ NMR and ${ }^{13} \mathrm{C}$ NMR chemical shifts $\delta$ are reported in $\mathrm{ppm}$ referenced to the protonated residual solvent signal. Mass spectra (HRMS) were recorded by the mass spectrometry service at the Spectropôle Aix Marseille Université. Measurements were realized with two internal standards. ECD spectra were recorded on a Jasco J-815 spectrometer in $\mathrm{CH}_{2} \mathrm{Cl}_{2}$. CTV- $\mathrm{Br}$ derivative 3 was prepared according to the common published procedure. $^{28}$

\section{Compound 4}

In a $100-\mathrm{mL}$ round-bottom flask, $1.30 \mathrm{~g}(1.78 \mathrm{mmol})$ of 3 are dissolved in $40 \mathrm{~mL}$ of anhydrous dimethylformamide (DMF) under argon atmosphere. Then $1.16 \mathrm{~g}(17.8 \mathrm{mmol})$ of $\mathrm{NaN}_{3}$ are added by portions at room temperature. The mixture was stirred at $60^{\circ} \mathrm{C}$ overnight. After DMF evaporation, the crude product is dissolved in $100 \mathrm{~mL}$ of dichloro- methane and washed three times with water $(3 \times 100 \mathrm{~mL})$, then with brine $(150 \mathrm{~mL})$, and dried over anhydrous $\mathrm{Na}_{2} \mathrm{SO}_{4}$. A yellowish oil was obtained after evaporation of the solvent under reduced pressure. Diethyl ether (70 $\mathrm{mL}$ ) was added, and the mixture was stored at $4^{\circ} \mathrm{C}$ for about 6 hours to give a white solid, which was filtered on a frit and washed with $\mathrm{Et}_{2} \mathrm{O}$ to yield 4 (990 mg, 90\%).

$R_{\mathrm{f}}\left(\mathrm{CH}_{2} \mathrm{Cl}_{2}\right): 0.23 ;{ }^{1} \mathrm{H}$ NMR $\left(\mathrm{CDCl}_{3}, 300 \mathrm{MHz}\right) \delta 6.93$ (s, 3H), $6.85(\mathrm{~s}, 3 \mathrm{H}), 4.75(\mathrm{~d}, J=13.7 \mathrm{~Hz}, 3 \mathrm{H}), 4.14(\mathrm{t}$, $J=5.2 \mathrm{~Hz}, 6 \mathrm{H}$ ), 3.83 (s, 9H), 3.59 to $3.52(\mathrm{~m}, 9 \mathrm{H}) ;{ }^{13} \mathrm{C}$ NMR $\left(\mathrm{CDCl}_{3}, 75 \mathrm{MHz}\right) \delta 149.2,146.5,133.9,131.9$, 118.1, 114.2, 69.1, 56.1, 50.3, and 36.4; IR $\sigma=2931$, 2110, 1511, and $1265 \mathrm{~cm}^{-1}$; and HRMS (ESI-TOF) $\mathrm{m} / z$ : observed $638.2442[\mathrm{M}+\mathrm{Na}]^{+}$(calculated: 638.2446 for $\left.\mathrm{C}_{30} \mathrm{H}_{33} \mathrm{~N}_{9} \mathrm{O}_{6} \mathrm{Na}\right) .{ }^{14}$

\section{Compound 5}

In a $250-\mathrm{mL}$ round-bottom flask, $490 \mathrm{mg}(0.796 \mathrm{mmol})$ of azide 4 are dissolved in THF $(15 \mathrm{~mL})$ and water $(0.5 \mathrm{~mL})$ and $3.75 \mathrm{~g}(14.3 \mathrm{mmol})$ of $\mathrm{PPh}_{3}$ are added by portions at $0^{\circ} \mathrm{C}$. The mixture is then allowed to warm to room temperature. After 24 hours of stirring at room temperature, solvents are evaporated. Diethyl ether $(50 \mathrm{~mL})$ was added to the resulting solid and the mixture was stirred at r.t. for 24 hours. Filtration afforded compound $\mathbf{5}$ as a white powder (391 mg, $91 \%$ ).

$R_{\mathrm{f}}\left(\mathrm{CH}_{2} \mathrm{Cl}_{2} / \mathrm{MeOH}: 97 / 3\right): 0.05 ;{ }^{1} \mathrm{H}$ NMR $\left(\mathrm{CDCl}_{3}, 400\right.$ MHz) $\delta 6.88(\mathrm{~s}, 3 \mathrm{H}), 6.82(\mathrm{~s}, 3 \mathrm{H}), 4.75(\mathrm{~d}, J=13.7 \mathrm{~Hz}$, $3 \mathrm{H}), 4.10$ to $3.92(\mathrm{~m}, 6 \mathrm{H}), 3.82(\mathrm{~s}, 9 \mathrm{H}), 3.53$ (d, $J=13.4$ $\mathrm{Hz}, 3 \mathrm{H}), 3.05$ (t, $J=5.2 \mathrm{~Hz}, 6 \mathrm{H}) ;{ }^{13} \mathrm{C}$ NMR $\left(\mathrm{CDCl}_{3}, 100\right.$ $\mathrm{MHz}) \delta 148.5,146.9,132.6,131.9,116.1,113.8,72.0$, 56.2, 41.6, and 36.5; IR $\sigma=3430,2935,1511$, and 1263 $\mathrm{cm}^{-1}$; and HRMS (ESI-TOF) $\mathrm{m} / \mathrm{z}$ : observed 538.2913 $[M+\mathrm{H}]^{+}$(calculated: 538.2912 for $\mathrm{C}_{30} \mathrm{H}_{40} \mathrm{~N}_{3} \mathrm{O}_{6}$ ). ${ }^{14}$

\section{Hemicryptophane 1}

In a 1-L round-bottom flask, $\mathrm{CTV}-\mathrm{NH}_{2}$ derivative 5 (354 $\mathrm{mg}, 0.658 \mathrm{mmol}$ ) was dissolved in anhydrous $\mathrm{CH}_{2} \mathrm{Cl}_{2}$ $(300 \mathrm{~mL})$, then, $\mathrm{ET}_{3} \mathrm{~N}(2.0 \mathrm{~mL})$ was added. A solution of 1,3,5-benzenetricarbonyl trichloride (192 $\mathrm{mg}, 0.723 \mathrm{mmol}$ ) in anhydrous $\mathrm{CH}_{2} \mathrm{Cl}_{2}(220 \mathrm{~mL})$ was slowly added dropwise over 24 hours under stirring at $30^{\circ} \mathrm{C}$, and the reaction mixture was stirred at $30^{\circ} \mathrm{C}$ for 24 hours. The mixture was then filtered and concentrated under reduced pressure. $\mathrm{CH}_{2} \mathrm{Cl}_{2}(60 \mathrm{~mL})$ was added, and the organic layer was washed with aqueous $\mathrm{K}_{2} \mathrm{CO}_{3}(10 \%, 70 \mathrm{~mL})$ and water $(70 \mathrm{~mL})$. Aqueous phases were combined and extracted with $\mathrm{CH}_{2} \mathrm{Cl}_{2}(70 \mathrm{~mL})$. The combined organic layers were dried over $\mathrm{MgSO}_{4}$, and the organic solvent was removed under reduced pressure to afford a white solid purified by silica gel column chromatography $\left(\mathrm{CHCl}_{3} / \mathrm{MeOH}\right.$, gradient from 95/5-91/9). Racemic hemicryptophane 1 was obtained as a white solid (132 mg, 29\%). 
$R_{\mathrm{f}}\left(\mathrm{CHCl}_{3} / \mathrm{MeOH}: 93 / 7\right): 0.32 ;$ m.p. greater than $310^{\circ} \mathrm{C}$ (decomposition); ${ }^{1} \mathrm{H}$ NMR $\left(\mathrm{CDCl}_{3}, 500 \mathrm{MHz}, 298 \mathrm{~K}\right) 7.52$ (s, 1H), $6.78(\mathrm{~s}, 1 \mathrm{H}), 6.72(\mathrm{~s}, 1 \mathrm{H}), 6.66(\mathrm{dd}, J=7.2,4.7 \mathrm{~Hz}$, $1 \mathrm{H}), 4.80$ (td, $J=11.9,2.9 \mathrm{~Hz}, 1 \mathrm{H}), 4.43(\mathrm{~d}, J=13.9 \mathrm{~Hz}$, $1 \mathrm{H}), 4.27(\mathrm{dd}, J=12.3,3.0 \mathrm{~Hz}, 1 \mathrm{H}), 4.22(\mathrm{~s}, 3 \mathrm{H}), 4.04$ (ddd, $J=13.8,7.7,1.6 \mathrm{~Hz}, 1 \mathrm{H}$ ), 3.43 (ddt, $J=15.9,11.6$, $4.6 \mathrm{~Hz}, 1 \mathrm{H}), 3.27$ (d, $J=14.0 \mathrm{~Hz}, 1 \mathrm{H}) ;{ }^{13} \mathrm{C} \mathrm{NMR}\left(\mathrm{CDCl}_{3}\right.$, $100 \mathrm{MHz}, 298$ K) $\delta 164.18,147.70,147.26,132.42,131.49$, 131.41, 126.76, 116.76, 113.79, 77.44, 77.02, 76.60, 66.98, 56.04, 42.17, and 36.73; IR $\sigma=3383,2918,2851,1663$, 1515, 1457, 1258, and $1082 \mathrm{~cm}^{-1}$; and HRMS (ESI-TOF) $m / z$ : observed $694.2758[M+\mathrm{H}]^{+}$(calculated: 694.2759 for $\mathrm{C}_{39} \mathrm{H}_{40} \mathrm{~N}_{3} \mathrm{O}_{9}$ ).

\section{2 | Resolution by chiral HPLC}

\subsection{1 | Methods}

The chiral HPLC separations were performed on Agilent 1260 Infinity unit (pump G1311B, autosampler G1329B, DAD G1315D). Analytical $(250 \times 4.6 \mathrm{~mm}, 5 \mu \mathrm{m})$ and preparative $(250 \times 10 \mathrm{~mm}, 5 \mu \mathrm{m})$ Chiralpak IB from Chiral Technologies Europe (Illkirch, France) are used. Preparative chiral HPLC is performed on Chiralpak IB $(250 \times 10 \mathrm{~mm})$ column with hexane/ethanol/dichloromethane $(50 / 30 / 20)$ as mobile phase. Flow rate was $5 \mathrm{~mL} / \mathrm{min}$ and ultraviolet (UV) detection was done at $254 \mathrm{~nm}$. About $50 \mathrm{mg}$ of the racemic mixture of $\mathbf{1}$ are dissolved in $3.2 \mathrm{~mL}$ of $\mathrm{CH}_{2} \mathrm{Cl}_{2}$. Injections were stacked $(32 \times 100 \mu \mathrm{L}$, every 8 minutes $)$.

\subsection{2 | Instrumentation}

Optical rotations were measured on a Jasco P-2000 polarimeter with a sodium lamp (589 nm), a halogen lamp (578, 546, 436, 405, and $365 \mathrm{~nm})$, in a $10 \mathrm{~cm}$ cell, thermostated at $25^{\circ} \mathrm{C}$ with a Peltier-controlled cell holder. ECD and UV spectra were measured on a JASCO J-815 spectrometer equipped with a JASCO Peltier cell holder PTC-423 to maintain the temperature at $25.0 \pm 0.2^{\circ} \mathrm{C}$ using a quartz cell of optical pathlength of $1 \mathrm{~mm}$. The ECD spectrometer was purged with nitrogen before recording each spectrum, which was baseline subtracted. The baseline was always measured for the same solvent and in the same cell as the samples. The spectra are presented without smoothing and further data processing.

\subsection{3 | Conformational search and simu- lations of ECD spectra}

Conformational search was carried out at the molecular mechanics level using calculations at the MM2 level. Then, the lowest energy structure was selected for DFT optimization with standard parameters and convergence criteria, which were run using Gaussian16 program at the B3LYP/6-31G(d) level of theory applying PCM for $\mathrm{CH}_{3} \mathrm{CN}$. Finally, ECD calculations were run at TDDFT level for the first 250 excited electronic by using the CAM-B3LYP and B3LYP functionals with singular value decomposition (SVD) basis set in PCM model for $\mathrm{CH}_{3} \mathrm{CN}$. Since they gave very similar results, for the sake of clarity, in the main text are only presented results from CAM-B3LYP functional and SVD basis set (see also Figure S11).

\subsection{4 | Resolution}

The resolution of the racemic mixture was performed by chiral HPLC using a Chiralpak IB $(250 \times 10 \mathrm{~mm})$ column with heptane/EtOH/ $\mathrm{CH}_{2} \mathrm{Cl}_{2}(50 / 30 / 20)$ as mobile phase to yield the two enantiopure hemicryptophanes (+)-1 (ee $>99.5 \%)$ and $(-)-1$ (ee $>97.5 \%)$.

$M(-):[\alpha]_{D}^{25}\left(\mathrm{CH}_{2} \mathrm{Cl}_{2}, \mathrm{c}=0.16\right)=-78 ; P(+):[\alpha]_{D}^{25}$ $\left(\mathrm{CH}_{2} \mathrm{Cl}_{2}, \mathrm{c}=0.19\right)=+79$;

\section{3 | RESULTS AND DISCUSSION}

\section{1 | Synthesis of hemicryptophane 1}

Hemicryptophane $\mathbf{1}$ was obtained according to the synthetic pathway shown in Scheme 1. Our previously described two-steps procedure provides the CTV derivative 3 as a racemic mixture: vanillyl alcohol 2 first reacts with 1,2-dibromoethane, then Friedel-Crafts reactions catalyzed by scandium triflate in $\mathrm{CH}_{3} \mathrm{CN}$ gives the key CTV-3 with $20 \%$ overall yield. ${ }^{28}$ The CTV-4 is then synthesized by mixing CTV-3 with sodium azide in DMF. Addition of triphenyl phosphine to a solution of compound 4 in a $\mathrm{THF} / \mathrm{H}_{2} \mathrm{O}$ mixture provides the intermediate $\mathbf{5}$ in $91 \%$ yield. Hemicryptophane $\mathbf{1}$ was obtained by a final macrocyclization reaction step between 1,3,5benzenetricarbonyl trichloride and CTV-5 in the presence of triethylamine in dichloromethane (concentration of reactants: $10^{-3} \mathrm{M}$ ). Thus, host $\mathbf{1}$ was synthesized in five steps from vanillyl alcohol in $4.7 \%$ overall yield.

\section{2 | ${ }^{1}$ H NMR Of Hemicryptophane 1}

The ${ }^{1} \mathrm{H}$ NMR spectrum of hemicryptophane $\mathbf{1}$ in $\mathrm{CDCl}_{3}$ is shown in Figure 1 and demonstrates that this molecule displays, on average, a $C_{3}$ symmetry in solution. The expected signals of the CTV moiety can be observed: two singlets for the aromatic protons at 6.78 and $6.72 \mathrm{ppm}$, one singlet for the OMe group at $4.22 \mathrm{ppm}$, and the characteristic AB system for the diastereotopic protons of the $\mathrm{ArCH}_{2}$ bridges at 4.43 and $3.27 \mathrm{ppm}$. The diastereotopic $\mathrm{OCH}_{2} \mathrm{CH}_{2} \mathrm{~N}$ protons of the linkers give four well-defined signals at 4.80, 4.27, 

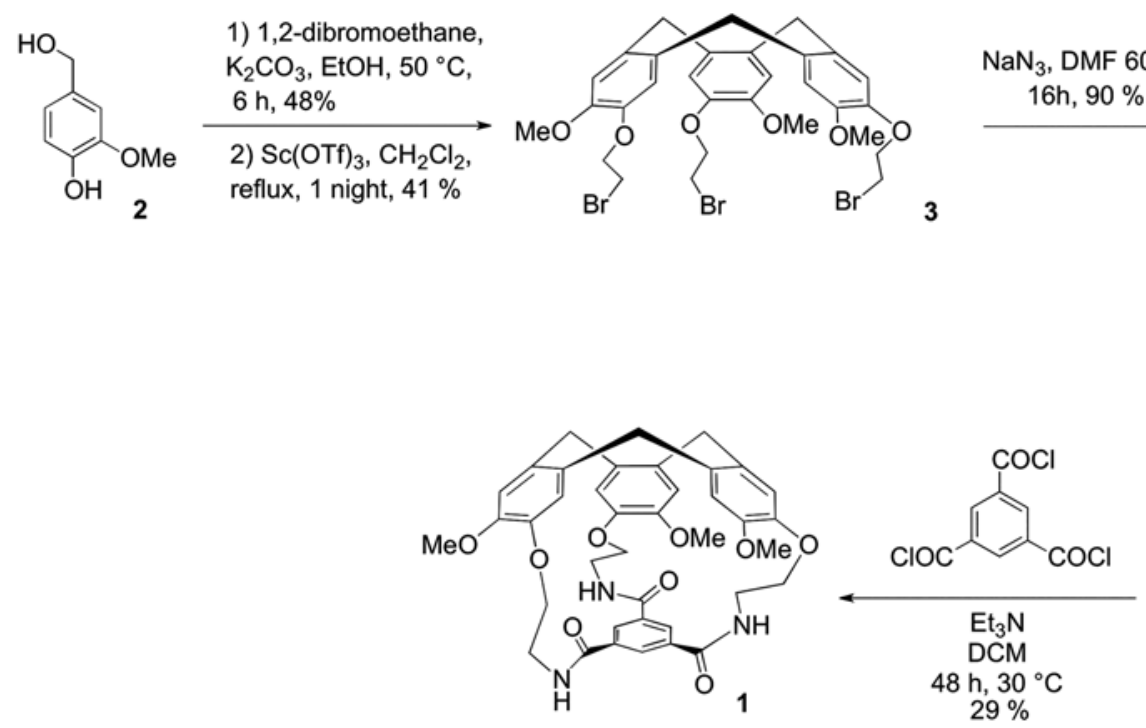

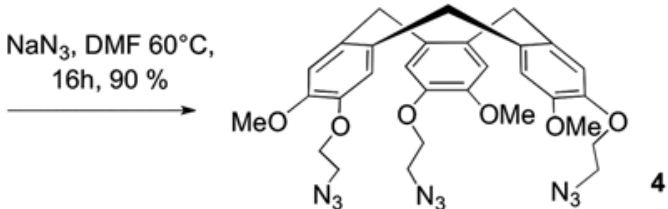

$\mathrm{PPh}_{3}, \mathrm{THF} / \mathrm{H}_{2} \mathrm{O}$

(30/1), r.t., $16 \mathrm{~h}$ $91 \%$

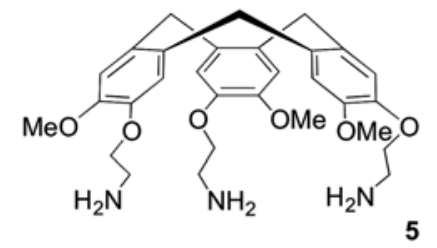

SCHEME 1 Synthesis of hemicryptophane 1.

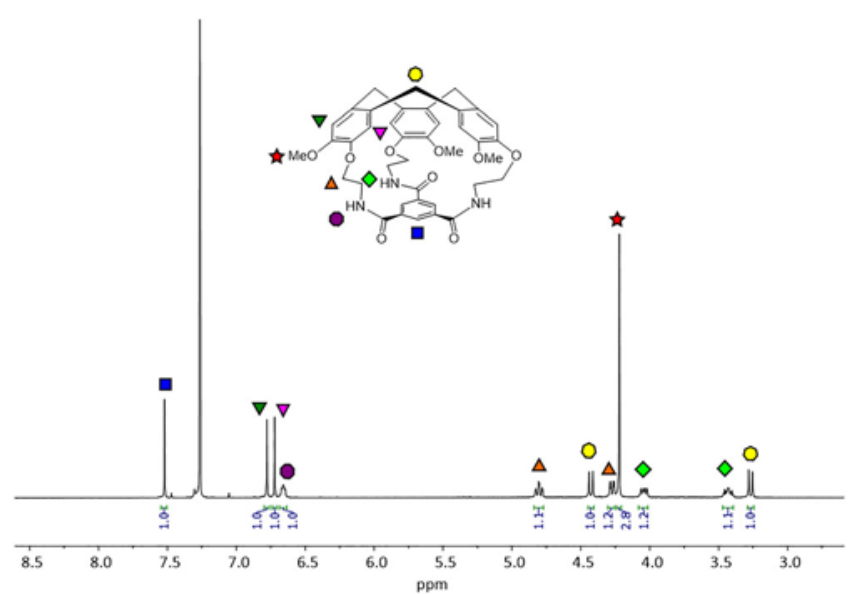

FIGURE $1{ }^{1} \mathrm{H}$ NMR spectrum $\left(500 \mathrm{MHz}, \mathrm{CDCl}_{3}\right)$ of $\mathbf{1}$

4.04, and $3.43 \mathrm{ppm}$. The aromatic protons of the benzene ring of the south unit appear as a singlet at $7.52 \mathrm{ppm}$. The signal for the amide protons is observed at $6.66 \mathrm{ppm}$.

\section{3 | Resolution of hemicryptophane 1}

The racemic mixture of $\mathbf{1}$ was resolved by semipreparative chiral HPLC on Chiralpak IB column, using heptane/EtOH/ $\mathrm{CH}_{2} \mathrm{Cl}_{2}(50 / 30 / 20)$ as the mobile

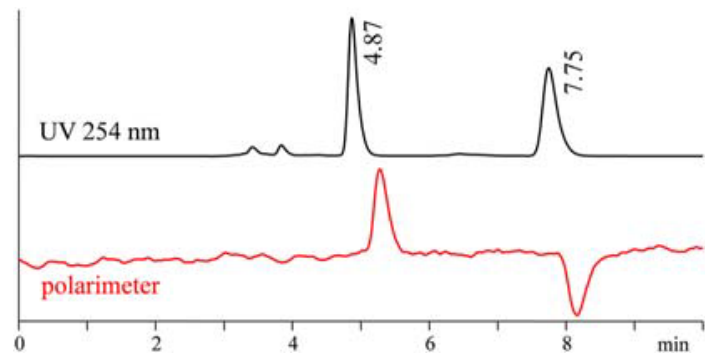

FIGURE 2 Chiral high-performance liquid chromatography (HPLC) chromatogram of the mixture of the two enantiomers of 1 phase (Figure 2). A resolution factor of 8.99 was measured, allowing isolating each enantiomer of the cage with ee $>99 \%$ for the first eluted enantiomer (+)-1, and ee $>97.5 \%$ for the second one (-)-1.

\section{4 | Assignment of the absolute configuration}

We then investigated the chiroptical properties of the two enantiomers of $\mathbf{1}$. Their optical rotations values are $+79\left([\alpha]_{\lambda}^{25}\left(\mathrm{CH}_{2} \mathrm{Cl}_{2}, \mathrm{c}=0.19\right)\right)$ and $-78\left([\alpha]_{\lambda}^{25}\left(\mathrm{CH}_{2} \mathrm{Cl}_{2}\right.\right.$, $\mathrm{c}=0.16)$ ) for the first and second eluted enantiomer, respectively, values typically in the range of those obtained for other enantiopure hemicryptophanes. ${ }^{29}$ This underlines that the optical rotation is poorly sensitive to the substituents of the hemicryptophane cage. Then, their ECD spectra were recorded in acetonitrile and are shown in Figure 3. Both spectra display the two expected exciton patterns centered on the isotropic absorption of the ${ }^{1} L_{\mathrm{a}}(\sim 240$ $\mathrm{nm})$ and ${ }^{1} L_{\mathrm{b}}(\sim 290 \mathrm{~nm})$ transitions. According to Collet et al, ${ }^{30}$ the sign of the ${ }^{1} L_{\mathrm{a}}$ bands around $240 \mathrm{~nm}$ can be used to assign the absolute configuration of CTV unit, because of its low sensitivity to the nature of substituents linked to the CTV part. Thus, the (+)-P-1 and (-)-M-1 configurations were assigned to the first and second eluted enantiomers, respectively. However, in order to enhance this assignment, the quantum chemical calculations of ECD spectra on TDDFT level were carried out. ECD spectrum of 1 was calculated for an arbitrary chosen $M$-enantiomer using hybrid functional CAM-B3LYP with the SVP basis set and PCM model for $\mathrm{CH}_{3} \mathrm{CN}$. This level of theory was indicated by us earlier as the preferred one for capturing electronic chiroptical properties of CTV systems. ${ }^{31,32}$ The calculated spectrum is in line with experimental one in the range of 190 to $260 \mathrm{~nm}$, which involves ${ }^{1} L_{\mathrm{a}}$ and ${ }^{1} L_{\mathrm{b}}$ 


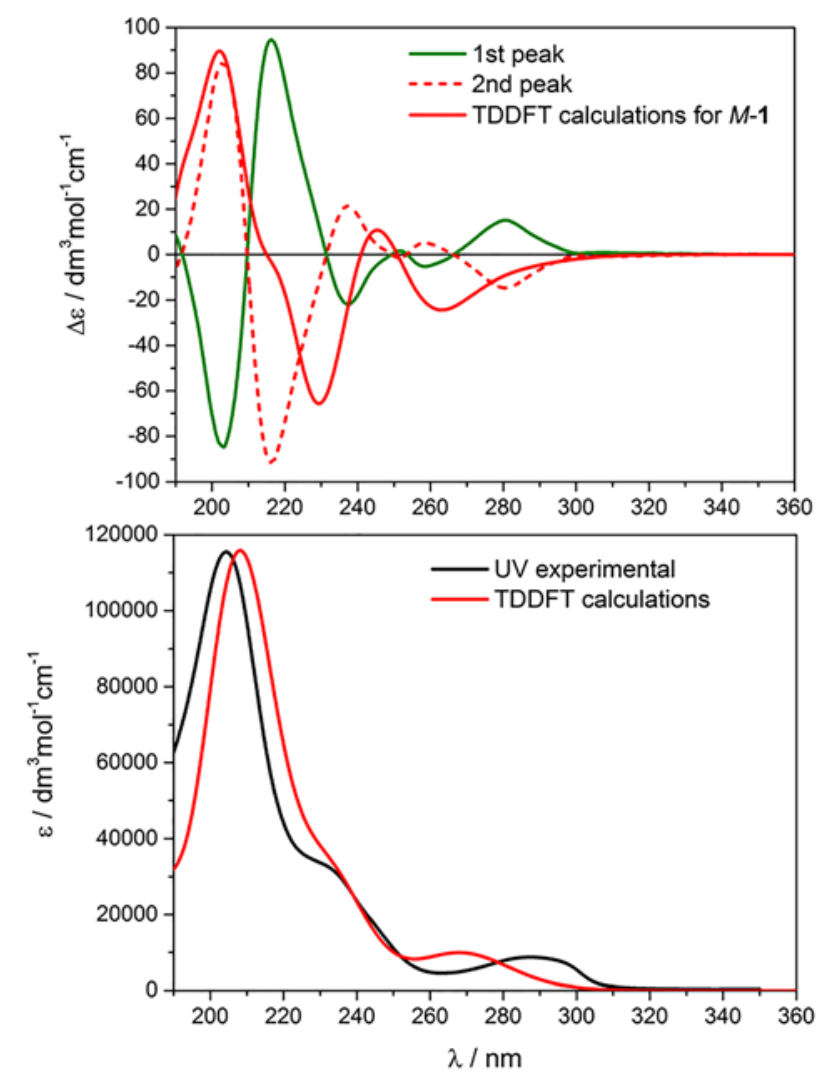

FIGURE 3 Experimental electronic circular dichroism (ECD) spectra of the enantiomers of $\mathbf{1}$ : the first eluted enantiomer is represented with a green solid line $\left(0.165 \mathrm{mmol}^{-1}\right.$ in $\left.\mathrm{CH}_{3} \mathrm{CN}\right)$ and the second one by a red dotted line $\left(0.166 \mathrm{mmol}^{-1} \mathrm{~L}^{-1} \mathrm{CH}_{3} \mathrm{CN}\right)$ together with TDDFT calculations performed for $M$-1. Calculations were carried out at the CAM-B3LYP/SVP/PCM $\left(\mathrm{CH}_{3} \mathrm{CN}\right)$ level of theory; spectrum red shifted by $15 \mathrm{~nm}$, Gaussian bandwidth 0.33 $\mathrm{eV}$. Below the ECD, the calculated and experimental UV spectra of 1 can be found

transitions. (Figure 3). This confirms again the aforementioned sterochemical assignments based on ECD ${ }^{1} L_{\mathrm{a}}$ bands, highlighting another time the universal character of experiment correlation found by Collet et $\mathrm{al}^{30}$ for CTV unit.

\section{5 | Solid-state structure of hemicryptophane 1}

Crystals suitable for X-ray diffraction were obtained by slow evaporation of a solution of hemicryptophane rac-1 in $\mathrm{CHCl}_{3}$. The X-ray structure reveals that the hemicryptophane cage crystallizes as a racemate in the space group $\mathrm{Pba} 2$ and exhibits a $C_{3}$ symmetry, in agreement with ${ }^{1} \mathrm{H}$ NMR spectrum (Figure 4). Interestingly, rac-1 crystallizes with two independent configurations in the asymmetric unit. The capped BTA unit presents a structurally chiral conformation where the three amides are oriented in similar direction giving rise to a right-
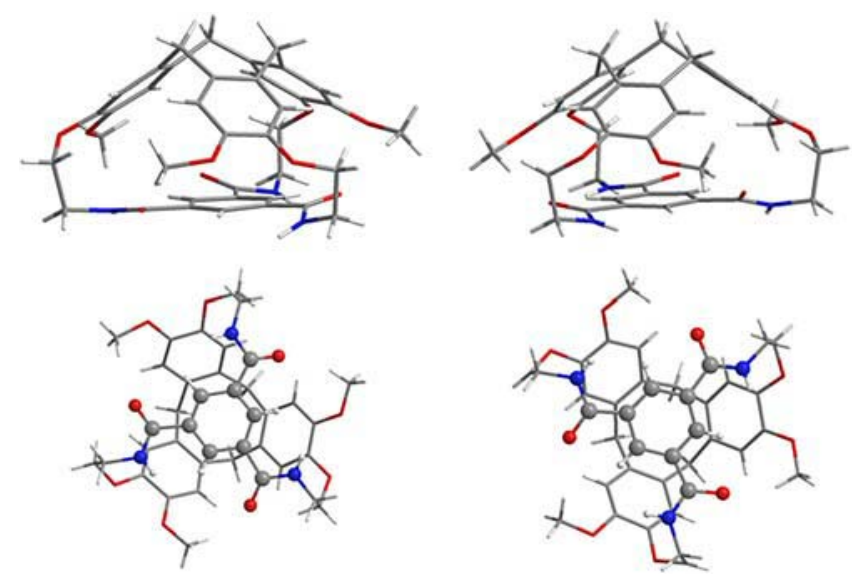

FIGURE 4 X-ray crystal structure of (-)-M-1 (left) and (+)-P-1 (right)

handed or left-handed propeller. Thus, the chirality of the CTV moiety controls the chirality of propeller-like arrangement of the capped BTA unit: the $M$ configuration of the CTV imposes a $\Lambda$ orientation of the amides groups, whereas the $P$ one leads to a $\Delta$ arrangement of these functions. This highlights the ability of the CTV unit to transfer its chirality to the south part of the cage. This chiral arrangement of the amides is probably retained in solution, since only one set of signal (single diastereomer) is observed on the ${ }^{1} \mathrm{H}$ NMR spectrum.

\section{4 | CONCLUSION}

In conclusion, we have described the synthesis of a new hemicryptophane cage combining a CTV unit with a BTA moiety. The resolution of the racemic mixture was performed by chiral HPLC allowing for the isolation of each enantiomer with good enantiopurity. The assignment of their absolute configuration was achieved using ECD spectroscopy. The X-ray molecular structure shows that, in the solid state, the amide functions of the lower part adopt a chiral orientation, which is controlled by the chirality of the CTV unit. This strong control on the chirality of other chiral-linked units has been already reported for other hemicryptophane cages: for instance with the helical arrangement of the linkers involving intramolecular hydrogen bonding or metal complexation, ${ }^{18,33}$ with the propeller arrangement of atrane units, ${ }^{34,35}$ or with remote chiral tren unit. ${ }^{31}$ Thus, this ability of the chirality of the CTV unit to propagate along its linker appears as quite general and efficient even with remote stereogenic units. Taking advantage of this remarkable property, we envisage to build highly functionalized hemicryptophane cages to complex lanthanide metals and to control efficiently the chirality at the metal center with that of the CTV unit in order to provide enantiopure molecular cages for circularly polarized luminescence (CPL) applications. 
1. Gabard J, Collet A. Synthesis of a (D3)-bis (cyclotriveratrylenyl) macrocage by stereospecific replication of a (C3)-subunit. $J$ Chem Soc Chem Comm. 1981;1137-1139.

2. Brotin T, Dutasta JP. Cryptophanes and their complexes-present and future. Chem Rev. 2009;109:88-130.

3. Garel L, Dutasta JP, Collet A. Complexation of methane and chlorofluorocarbons by cryptophane-A in organic solution. Angew Chem Int Ed. 1993;22:169-1171.

4. Bartik K, Luhmer M, Dutasta JP, Collet AR, J. ${ }^{129} \mathrm{Xe}$ and ${ }^{1} \mathrm{H}$ NMR study of the reversible trapping of xenon by cryptophane-A in organic solution. $\mathrm{J}$ Am Chem Soc. 1998;120:784-791.

5. Fairchild RM, Holman KT. Selective anion encapsulation by a metalated cryptophane with a $\pi$-acidic interior. $J$ Am Chem Soc. 2005;127:16364-16365.

6. Brotin T, Montserret R, Bouchet A, Cavagnat D, Linares M, Buffeteau T. High affinity of water-soluble cryptophanes for cesium cations. J Org Chem. 2012;77:1198-1201.

7. Garel L, Lozach B, Dutasta JP, Collet A. Remarkable effect of the receptor size in the binding of acetylcholine and related ammonium ions to water-soluble cryptophanes. J Am Chem Soc. 1993;115:11652-11653.

8. Canceill J, Lacombe L, Collet A. Analytical optical resolution of bromochlorofluoromethane by enantioselective inclusion into a tailormade cryptophane and determination of its maximum rotation. J Am Chem Soc. 1985;107:6993-6996.

9. Bouchet A, Brotin $\mathrm{T}$, Linares $\mathrm{M}$, Ågren $\mathrm{H}$, Cavagnat $\mathrm{D}$, Buffeteau T. Enantioselective complexation of chiral propylene oxide by an enantiopure water-soluble cryptophane. J Org Chem. 2011;76:4178-4181.

10. Canceill J, Collet A, Gabard J, Kotzyba-Hibert F, Speleands LJM. Macropolycyclic receptor cages based on binding and shaping sub-units. Synthesis and properties of macrocycle cyclotriveratrylene combinations. Helv Chim Acta. 1982;65:1894-1897.

11. Zhang D, Martinez A, Dutasta JP. Emergence of hemicryptophanes: from synthesis to applications for recognition, molecular machines, and supramolecular catalysis. Chem Rev. 2017;117:4900-4942.

12. Hardie MJ. Recent advances in the chemistry of cyclotriveratrylene. Chem Soc Rev. 2010;39:516-527.

13. Brotin T, Guy L, Martinez A, Dutasta JP. Enantiopur supramolecular cages: synthesis and chiral recognition Properties. Top Curr Chem. 2013;341:177-230.

14. Long A, Perraud O, Albalat M, Robert V, Dutasta JP, Martinez A. Helical chirality induces a substrate-selectivity switch in carbohydrates recognitions. J Org Chem. 2018;83:6301-6306.
15. Zhang D, Mulatier JC, Cochrane JR, et al. Helical, axial, and central chirality combined in a single cage: synthesis, absolute configuration, and recognition properties. Chem Eur J. 2016;22:8038-8042.

16. Perraud O, Robert V, Gornitzka H, Martinez A, Dutasta JP. Gathering cation- $\pi$ and anion- $\pi$ interactions for zwitterions recognition. Angew Chem Int Ed. 2012;51:504-508.

17. Schmitt A, Chatelet B, Collin S, Dutasta JP, Martinez A. Chiral discrimination of ammonium neurotransmitters by $C_{3}$-symmetric enantiopure hemicryptophane hosts. Chirality. 2013;25: 475-479.

18. Long A, Perraud O, Jeanneau E, Aronica C, Dutasta JP, Martinez A. A hemicryptophane with a triple-stranded helical structure. Beilstein J Org Chem. 2018;14:1885-1889.

19. Zimbron JM, Caumes X, Li Y, Thomas CM, Raynal M, Bouteiller L. Real-time control of the enantioselectivity of a supramolecular catalyst allows selecting the configuration of consecutively formed stereogenic centers. Angew Chem Int Ed. 2017;56:14016-14019.

20. Kulkarni C, Meijer EW, Palmans ARA. Cooperativity scale: a structure-mechanism correlation in the self-assembly of benzene-1,3,5-tricarboxamides. Acc Chem Res. 2017;50: 1928-1936.

21. Das A, Vantomme G, Markvoort A, et al. Supramolecular copolymers: structure and composition revealed by theoretical modeling. J Am Chem Soc. 2017;139:7036-7044.

22. Garzoni M, Baker MB, Leenders CMA, et al. Effect of H-bonding on order amplification in the growth of a supramolecular polymer in water. J Am Chem Soc. 2016;138:13985-13995.

23. Desmarchelier A, Caumes X, Raynal M, Vidal-Ferran A, van Leeuwen PWNM, Bouteiller L. Correlation between the selectivity and the structure of an asymmetric catalyst built on a chirally amplified supramolecular helical scaffold. J Am Chem Soc. 2016;138:4908-4916.

24. Caumes X, Baldi A, Gontard G, et al. Bouteiller L Tuning the structure of 1,3,5-benzene tricarboxamide self-assemblies through stereochemistry. Chem Commun. 2016;52:13369-13372.

25. Desmarchelier A, Raynal M, Brocorens P, Vanthuyne N, Bouteiller L. Revisiting the assembly of amino ester-based benzene-1,3,5-tricarboxamides: chiral rods in solution. Chem Commun. 2015;51:7397-7400.

26. Gillissen MAJ, Koenigs MME, Spiering JJH, et al. Triple helix formation in amphiphilic discotics: demystifying solvent effects in supramolecular self-assembly. $\mathrm{J} \mathrm{Am}$ Chem Soc. 2014;136:336-343.

27. Raynal M, Portier F, van Leeuwen PWNM, Bouteiller L. Tunable asymmetric catalysis through ligand stacking in chiral rigid rods. J Am Chem Soc. 2013;135:17687-17690.

28. Chatelet B, Payet E, Perraud O, et al. Shorter and modular synthesis of hemicryptophane-tren derivatives. Org Lett. 2011;13:3706-3709.

29. Lefevre S, Zhang D, Godart E, et al. Large-scale synthesis of enantiopure molecular cages: chiroptical and recognition properties. Chem Eur J. 2016;22:2068-2074.

30. Canceill J, Collet A, Gabard J, Gottarelli G, Spada GP. Exciton approach to the optical activity of $C_{3}$-cyclotriveratrylene derivatives. J Am Chem Soc. 1985;107:1299-1308. 
31. Chatelet B, Joucla L, Padula D, et al. Remote control of helical chirality: thermodynamic resolution of a racemic mixture of CTV units by remote stereogenic centers. Org Lett. 2015; 17:500-503.

32. Long A, Colomban $\mathrm{C}$, Jean $\mathrm{M}$, et al. Enantiopure $C_{1^{-}}$ cyclotriveratrylene with a reversed spatial arrangement of the substituents. Org. Lett. 2019;21:160-165.

33. Gosse I, Robeyns K, Bougault C, Martinez A, Tinant B, Dutasta JP. Synthesis and structural studies of gallium (III) and iron (III) hemicryptophane complexes. Inorg Chem. 2016;55:1011-1013.

34. Martinez A, Robert V, Gornitzka H, Dutasta JP. Controlling helical chirality in atrane structures: solvent dependent chirality sense in hemicryptophane oxidovanadium(V) complexes. Chem Eur J. 2010;16:520-527.

35. Martinez A, Guy L, Dutasta JP. Reversible, solvent-induced chirality switch in atrane structure: control of the unidirectional motion of the molecular propeller. J Am Chem Soc. 2010;132:16733-16734. 